\title{
ICT Based Education - Tools, Advantages and Challenges
}

\author{
Rajkumar Sreepadapu ${ }^{1}$, Swathi Polasa ${ }^{2}$ \\ ${ }^{1}$ Head of Mechanical Engg., Section, Sanjay Gandhi Government Polytechnic, Adilabad, Telangana State, India \\ ${ }^{2}$ Senior Lecturer, Electrical and Electronics Engineering, Government Polytechnic, Nirmal, Telangana State, India
}

\begin{abstract}
Information Communication Technology (ICT) tools contribute to high quality lessons since they have potential to increase students' motivation, connect students to many information sources, support active in-class and outclass learning environments. ICT based Education allows the teacher to produce and modify resources quickly and easily. It allows access to a wide range of information in various formats, and Interactive Whiteboards (IWBs) have become essential tools in the classroom. ICT can be used in conducting tests, to score the tests, to analyze the result and to facilitate teachers in assessing learning outcomes. ICT can also support students to complete their projects and other academic activities.

In this Paper Various Tools for ICT based Education, Advantages and challenges are presented.
\end{abstract}

Keywords: ICT, ICT Tools, Advantages, Challenges.

\section{INTRODUCTION}

Following are the general ICT tools required for Teaching and Learning process and Computer skills required for every teacher.

\subsection{General ICT tools for teaching and learning}

- Desktop and laptops.

- Projector.

- Digital cameras.

- $\quad$ Printer.

- Photocopier.

- Tablets.

- $\quad$ Pen Drive.

\subsection{Computer skills required for every teacher}

- $\quad$ Word Processing Skills....

- $\quad$ Spreadsheet Skills. ...

- $\quad$ Database Management Skills. ...

- $\quad$ Electronic Presentation Skills....

- $\quad$ Internet Navigation Skills....

- $\quad$ Email Management Skills....

- $\quad$ Networking Skills. ...

- $\quad$ Touch Typing.

\section{ADVANTAGES OF ICT IN EDUCATION}

- $\quad$ Enhanced the modes of communication.

- $\quad$ Cost-efficient.

- $\quad$ Paperless: Eliminate the usage of paper. ...

- $\quad$ Better teaching and learning methods.

- $\quad$ Enhanced data and information security.

- $\quad$ Minimize cost and save time.

- $\quad$ Easy student management.

- $\quad$ Automatic solutions to manual paper-based process and procedures. 


\section{International Advanced Research Journal in Science, Engineering and Technology}

Vol. 8, Issue 6, June 2021

\section{DOI: $10.17148 / I A R J S E T .2021 .8634$}

Overall, the key issues and challenges found to be significant in using ICT tools by teachers were: limited accessibility and network connection, limited technical support, lack of effective training, limited time and lack of teachers' competency and interest.

Compared to earlier period, With the availability of computers in schools and colleges, students can carry out research quickly and finish off their assignments and projects much before the stipulated timeframe. This saves them a lot of time, and increase their knowledge in using the machines and latest technology. Information and communication technology offer a wide range of effective lessons and information. Use of word processing aids students to perform their assignments easily. It makes their projects and assignments presentable, clean and organized.

The major barriers were lack of genuine software, inadequate computer in the classroom, low speed internet, lack of motivation from both teacher and student side to use ICT, lack of proper training skills, unavailability of latest ICT equipment, lack of expert technical staff, poor administrative support, online abusing, Psychological effects, health problems of eye strain etc., which need to be addressed properly to get the benefits of latest technology of ICT.

3. Some of the different ICT tools and its usage for Teaching and students learning process as per reference [1] \& [3] and just for awareness (Correctness not checked).

Google Forms- Easy for quizzes, evaluations or questionnaires

Google ClassRoom: Teaching Learning environment

PPT Presentation: For best delivery of Subject and Learning

Various Video Conferencing Tools : For Teaching Learning environment

Certification tools: To encourage the Students by conducting quizzes, exams and certification.

\section{GLOBAL DIGITAL LIBRARY}

This digital library offers free accessible eBooks in more than 40 languages readable on the web, mobile, or for downloading and printing. The books can also betranslated or localized directly on the platform.

Cobo Cards - The best online flashcard software.

Cram- Find flashcards to study or create your own

Learning Pod-Targeted practice questions for student success.

Vocabulary- Acquire vocabulary easily

Canva- It makes design simple for everyone. Create designs for Web or print: blog graphics, presentations, Facebook covers, flyers, posters, invitations and so much more.

Infogram- Create and publish beautiful visualizations of your data in charts andinfographics. Interactive, responsive, and engaging.

Scribble Map- The Easiest Way to Draw and Share Maps

Gooru- Give your students free tools, digital content, and data to own their learning

Read Write Think- Providing educators, parents, \& afterschool professionals with freeaccess to the highest quality materials for reading \& language arts instruction

Showbie-It is the fastest, easiest and most effective app for assignments and feedback onyour classroom devices

Answer Garden - Allows students to give answers which will show on the teacher's screen

Chart Go- The online chart maker. Create rich and colorful charts.

Coggle- The clear way to share complex information. Coggle is a collaborative mind-mappingtool that helps you make sense of complex things.

Huzaz- The place to showcase, discover and collect the videos that matter most 


\section{International Advanced Research Journal in Science, Engineering and Technology}

Vol. 8, Issue 6, June 2021

\section{DOI: $10.17148 / I A R J S E T .2021 .8634$}

Lino it- Create and share canvases with post-its and other online tools

Mind Mo- Easy-to-create and share mind maps, concept maps, task maps and outlines. Mindmapping software for Web, Desktop, iOS and Android. Mind map with us for free

ED Puzzle-Make any video your lesson.

Educreations -Create educational videos (iPad only)

Go Noodle- Discover hundreds of videos that get your kids active at school and at home

Kahoot- Interactive and motivational quiz

Learn Click- Create online cloze quizzes. Simply mark words to turn them into gaps,dropdown or drag \& drop quizzes Flubaroo- Assess and evaluate student's work/progress online

Formative- A free platform for creating formative assessments + acting on real-time studentinsights

Lesson up- Create fun and engaging digital lessons

Mentimeter- Create graphics at an instant using students' input

Near pod- Create interactive slideshows, using questions, quizzes, images \& text

Google Docs- Work on the same document at the same time

Evernote- Capture, organize, and share notes from anywhere. Your best ideas are alwayswith you and always in sync. Class123-The best tool for classroom management and flipped classroom. Start buliding ahappy classroom community UNESCO also offers a comprehensive Digital learning solutions during pandemic, these arelisted out below.

Massive Open Online Course (MOOC) Platforms

Many other ICT tools are available on Internet. A user needs proper understanding, training and interest to acquaint online teaching and learning knowledge which makes easy to progress.

\section{CONCLUSION}

Technology is a versatile and valuable tool for teaching and learning and becoming a way of life. The most important thing is that teachers need to be prepared to use these technologies effectively. Academic institutions can use technology effectively and for the welfare of students, teachers and society, it must be done. ICT based Education also offers to raise standards in academic institutions and Students. ICT based Education can be combined with normal Physical mode of Teaching for high efficiency of Teaching Learning. Eventhough there are challenges one must start by taking benefits of latest technology which makes easier and effective.

\section{ACKNOWLEDGEMENTS}

The authors wish to acknowledge all as shown in references and indirect knowledge for contribution in this paper which throws light on importance of ICT based Education.

\section{REFERENCES}

[1]. Google search https://www.google.co.in

[2]. Short term training undergone in ICT TOOLS FOR TEACHING AND LEARNING 1 (ICT056) Conducted by National Institute of Technical Teachers Training and Research Institute (NITTTR), KOLKATA, INDIA

[3]. COVID - 19 \& uses of ICT tools By Dr. Anjusha J.Gawande, Educational Resurgence Journal Volume 2, Issue 4, July 2020 ISSN 2581-9100 